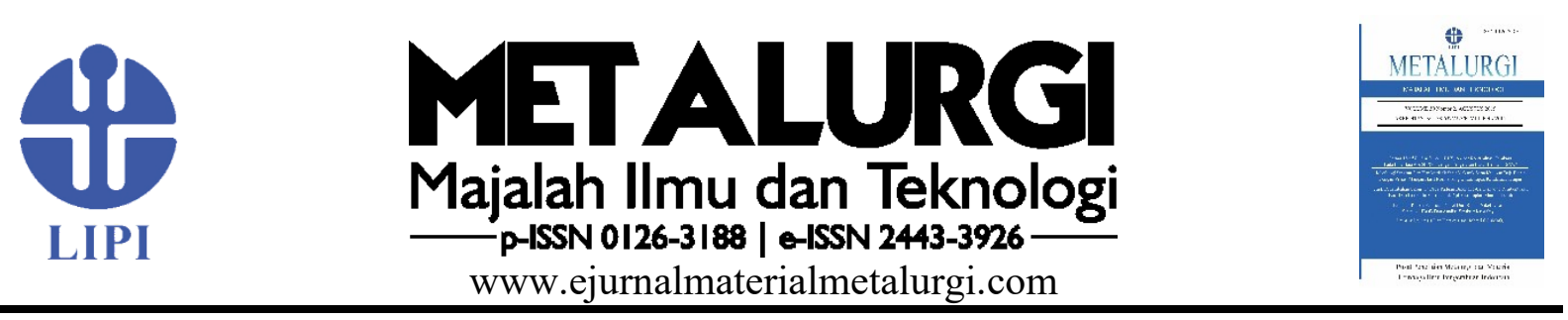

\title{
PengkayaAn UnSUR YTTRiUm dan CERiUm Pada TERAK TIMAH BANGKA: ANALISIS TERMODINAMIKA
}

\author{
Sulaksana Permanaa,*, Debby Rachel ${ }^{a}$, Agus Budi Prasetyo ${ }^{a, b}$, Rafdi Abdul Majid $^{\mathrm{c}}$, \\ Wahyu Kartika ${ }^{d}$, Iwan Susanto ${ }^{\mathrm{e}}$, Johny Wahyuadi Soedarsono ${ }^{\mathrm{a}}$ \\ ${ }^{a}$ Centre of Mineral Processing and Corrosion Research, Departemen Teknik Metalurgi and Material \\ Universitas Indonesia, Depok, Indonesia 16424 \\ ${ }^{\mathrm{b}}$ Pusat Penelitian Metalurgi dan Material - LIPI \\ Gedung 470 Kawasan Puspiptek Serpong, Indonesia 15310 \\ ${ }^{c}$ Departemen Teknik Kimia, Fakultas Teknik Industri, Universitas Muslim Indonesia, Makassar, Indonesia 90231 \\ ${ }^{\mathrm{d}}$ Departemen Teknik Lingkungan, Fakultas Teknik, Universitas Bhayangkara Jakarta Raya, \\ Kota Bekasi, Indonesia, 17121 \\ ${ }^{e}$ Departemen Teknik Mesin, Politeknik Negeri Jakarta, Indonesia 16425 \\ *E-mail: sulaksana@yahoo.com
}

Masuk tanggal : 20-07-2020, revisi tanggal : 28-07-2020, diterima untuk diterbitkan tanggal 29-07-2020

\begin{abstract}
Abstrak
Pada penelitian ini, terak timah Bangka-2 (TTB-2) dilakukan serangkaian kondisi proses untuk mendapatkan hasil pengkayaan yttrium dan cerium yang optimal. Proses yang dilakukan adalah dengan melakukan pemanggangan TTB-2 pada suhu $900{ }^{\circ} \mathrm{C}$, pelindian dengan $\mathrm{NaOH}$, pelindian dengan $\mathrm{HNO}_{3}$ dan terakhir pelindian dengan $\mathrm{H}_{3} \mathrm{PO}_{4}$ dengan variasi konsentrasi. Analisis termodinamika dilakukan dengan perangkat lunak HSC 6.0 untuk mendapatkan Diagram Eh-pH sistem Ca-Na- $\mathrm{H}_{2} \mathrm{O}$; Ce-Na- $\mathrm{H}_{2} \mathrm{O}$; Y-Na- $\mathrm{H}_{2} \mathrm{O}$; Ce- $-\mathrm{H}_{2} \mathrm{O} ; \mathrm{Y}-\mathrm{N}-\mathrm{H}_{2} \mathrm{O}$; Ce-P- $\mathrm{H}_{2} \mathrm{O}$ dan Y-P- $\mathrm{H}_{2} \mathrm{O}$ pada suhu $25{ }^{\circ} \mathrm{C}$ dengan tujuan melihat unsur yang terlarut ke dalam larutan $\mathrm{NaOH}, \mathrm{HNO}_{3}$ dan $\mathrm{H}_{3} \mathrm{PO}_{4}$. Hasil yang didapatkan adalah kadar optimal cerium 4,39\% setelah kondisi proses pelindian $\mathrm{NaOH}$ dan kadar yttrium mengalami peningkatan terus pada seluruh kondisi proses serta didapatkan kadar optimal 1,35\% setelah dilakukan pelindian dengan $\mathrm{HNO}_{3} 2 \mathrm{M}$ dan $\mathrm{H}_{3} \mathrm{PO}_{4} 1,5 \mathrm{M}$.
\end{abstract}

Kata Kunci: Cerium, pelindian, terak timah Bangka, unsur tanah jarang, yttrium

\begin{abstract}
In this analysis, the Bangka tin slag-2 (BTS-2) was carried out in a series of process conditions to obtain optimal yttrium and cerium enrichment results. The method is carried out by roasting BTS-2 at $900{ }^{\circ} \mathrm{C}$, leaching with $\mathrm{NaOH}$, leaching with $\mathrm{HNO}_{3}$, and finally leaching with $\mathrm{H}_{3} \mathrm{PO}_{4}$ with different concentrations. The thermodynamic analysis was performed using $\mathrm{HSC} 6.0$ software to obtain the $\mathrm{Ca}-\mathrm{Na}-\mathrm{H}_{2} \mathrm{O}$ Eh-pH diagram system; $\mathrm{Ce}-\mathrm{Na}-\mathrm{H}_{2} \mathrm{O}$; $\mathrm{Y}$ $\mathrm{Na}-\mathrm{H}_{2} \mathrm{O}$; $\mathrm{Ce}-\mathrm{N}-\mathrm{H}_{2} \mathrm{O} ; \mathrm{Y}-\mathrm{N}-\mathrm{H}_{2} \mathrm{O}$; $\mathrm{Ce}-\mathrm{P}-\mathrm{H}_{2} \mathrm{O}$ and $\mathrm{Y}-\mathrm{P}-\mathrm{H}_{2} \mathrm{O}$ at $25^{\circ} \mathrm{C}$ to see the leached elements in $\mathrm{NaOH}, \mathrm{HNO}_{3}$, and $\mathrm{H}_{3} \mathrm{PO}_{4}$ solutions. The results obtained were that the optimal cerium content was $4.39 \%$ after the NaOH leaching phase. The yttrium content continued to increase under all process conditions, and that the optimal cerium content

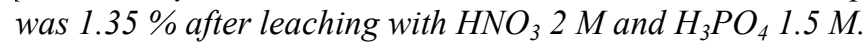

Keywords: Cerium, leaching, Bangka tin slag, rare earth element, yttrium

\section{Pendahuluan}

Unsur logam tanah jarang (UTJ) banyak digunakan pada teknologi saat ini seperti pada bidang elektronika, manufaktur, medis, teknologi laser, kendaraan hibrid, turbin angin, baterai nuklir dan baterai pengisi, katalis bahan bakar bio dan lainnya[1].

Karena begitu diperlukannya UTJ pada peralatan teknologi informasi (IT), hal inilah yang menyebabkan meningkat pesatnya permintaan UTJ seiring pertumbuhan yang tajam pada dunia IT tersebut[2]. Namun hal ini 
berkebalikan yang dilakukan oleh Cina sebagai pemimpin pasar dunia UTJ, dimana negara tersebut telah memperketat pembatasan ekspor UTJ terkonsentrasi. Hal inilah yang menyebabkan banyak negara melakukan penelitian dan eksplorasi pada sumber daya material baru seperti tambang perkotaan dan UTJ dengan tingkat konsentrasi rendah.

Penelitian sumber UTJ dari hasil samping penambangan dan pemurnian timah di kepulauan Bangka Belitung telah dilakukan oleh Krzysztof Szamalek dan kawan kawan [3]. Penelitian tentang UTJ pada TTB-2 diawali dengan melakukan analisis termodinamika dengan software HSC 6.0 pada kasus peningkatan kadar UTJ pada TTB [4], evaluasi pemrosesan termal ekstraksi dan pemisahan UTJ pada proses daur ulang sampah peralatan listrik dan elektronik juga menggunakan simulasi termodinamika software FactSage 7.2 untuk pelindian serbuk lampu fluoresen oleh asam sulfat [5].

Komposit mesopori berbasis perlit yang diperluas / expanded perlite-based (EPd-APTES (a) $\mathrm{Fe}_{3} \mathrm{O}_{4}$ ) dirancang dan disintesis sebagai adsorben baru untuk pengayaan ion tanah jarang dalam larutan air, parameter termodinamika menyatakan bahwa proses adsorpsi bersifat endotermik. Lebih penting lagi, studi adsorpsidesorpsi menunjukkan bahwa komposit bahan nano EPd-APTES@ $\mathrm{Fe}_{3} \mathrm{O}_{4}$ memiliki stabilitas tinggi dan kemampuan daur ulang yang baik [6].

Fenomena inklusi non-logam sebagai akibat dari penambahan yttrium sebagai komponen paduan pada baja cair, urutan pengenalan komponen individu menentukan kandungan akhir mereka dalam baja, dan masalah ini dianalisis menggunakan program WYK_Stal. Studi pengendapan fase $\mathrm{Y}_{2} \mathrm{O}_{3}$ dan $\mathrm{Y}_{2} \mathrm{~S}_{3}$ dan hubungan antara penambahan $\mathrm{Y}, \mathrm{Al}, \mathrm{Ca}, \mathrm{O}$, dan $\mathrm{S}$ pada baja cair dipelajari dengan menggunakan model termodinamika berdasarkan formalisme Wagner, jika yttrium dimasukkan setelah aluminium dan kalsium, yttrium digunakan untuk pengendapan sulfida, dan dengan cara ini pembentukan mangan sulfida berkurang [7].

Unsur racun potensial (Be, $\mathrm{U}, \mathrm{As}, \mathrm{Cd}, \mathrm{Pb}, \mathrm{Sb}$, Bi) terdeteksi untuk lanskap tambang deposit timah-polimetalik Sherlovaya Gora. Perhitungan kesetimbangan termodinamika air kolam pembuangan tailing dilakukan melalui program kompleks "Selektor" berdasarkan algoritma minimisasi $\Delta \mathrm{G}_{25}{ }^{\circ} \mathrm{C}$ dan tekanan total 1 bar, ternyata air tambang jenuh terhadap banyak sulfat $\mathrm{Ca}, \mathrm{Mg}, \mathrm{Sr}, \mathrm{Zn}, \mathrm{K}, \mathrm{Cu}, \mathrm{Ni}, \mathrm{Cd}, \mathrm{Be}, \mathrm{Al}, \mathrm{Ce}$ dan Y, fluorida (Ln dan Y, Sc), dan Y fosfat[8].

Tujuan dari penelitian ini adalah untuk mendapatkan pengkayaan dengan kadar optimal dari unsur cerium dan yttrium setelah TTB-2 dilakukan pemanggangan pada suhu $900{ }^{\circ} \mathrm{C}$ dan pencelupan ke dalam air, pelindian dengan $\mathrm{NaOH}$, pelindian dengan $\mathrm{HNO}_{3}$, dan pelindian dengan $\mathrm{H}_{3} \mathrm{PO}_{4}$ dengan variasi konsentrasi.

\section{Prosedur PercobaAn}

Penelitian ini dilakukan dengan beberapa kondisi proses, untuk memudahkan pembahasan dan mengefisiensikan kalimat serta penyebutan pada grafik maka dilakukan penyingkatan penyebutan. Beberapa penyingkatan penyebutan ditunjukkan pada Tabel 1.

Tabel 1. Kondisi proses dan simbol

\begin{tabular}{|c|c|}
\hline Simbol & Keterangan Kondisi Proses \\
\hline I & Terak Awal \\
\hline II & Pelindian dengan $\mathrm{NaOH} 8 \mathrm{M}$ \\
\hline III & Pelindian dengan $\mathrm{HNO}_{3} 2 \mathrm{M}$ \\
\hline IV & Pelindian dengan $\mathrm{HNO}_{3} 2 \mathrm{M}$ dilanjutkan dengan $\mathrm{H}_{3} \mathrm{PO}_{4} 0,5 \mathrm{M}$ \\
\hline $\mathrm{V}$ & Pelindian dengan $\mathrm{HNO}_{3} 2 \mathrm{M}$ dilanjutkan dengan $\mathrm{H}_{3} \mathrm{PO}_{4} \quad 1 \mathrm{M}$ \\
\hline VI & Pelindian dengan $\mathrm{HNO}_{3} 2 \mathrm{M}$ dilanjutkan dengan $\mathrm{H}_{3} \mathrm{PO} 41,5 \mathrm{M}$ \\
\hline
\end{tabular}

\subsection{Material dan Peralatan}

Sampel terak timah Bangka-2 didapatkan dari salah satu pabrik peleburan timah di kepulauan Bangka dan Belitung. Beberapa larutan kimia yang digunakan pada penelitian ini adalah larutan aquadest, $\mathrm{NaOH}$ (teknis) $8 \mathrm{M}$, larutan $\mathrm{HNO}_{3}$ (p.a) $2 \mathrm{M}$ dan larutan $\mathrm{H}_{3} \mathrm{PO}_{4} 0,5 \mathrm{M}$; $1 \mathrm{M} ; 1,5 \mathrm{M}$. Peralatan yang digunakan adalah ball mill, pengayak, barnstead thermolyne furnace, magnetic stirrer thermo scientific CIMAREC, spinbar Bel-Art ${ }^{\mathrm{TM}}$ scienceware ${ }^{\mathrm{TM}}$, gelas beaker, gelas ukur, labu takar, indikator $\mathrm{pH}$ dan oven MEMMERT UN55 Universal.

\subsection{Prosedur}

Pada tahap awal terak timah dilakukan proses pemanggangan pada suhu $900{ }^{\circ} \mathrm{C}$ selama 2 jam dilanjutkan pencelupan ke dalam air, dan setelah sampel terak timah Bangka-2 berada pada suhu kamar dan kering lalu dilakukan pengayakan. Sampel dengan ukuran butir $-200+250$ mesh dilakukan proses pelindian dengan $\mathrm{NaOH}$ dan selanjutnya dikeringkan, kemudian residu hasil pelindian basa selanjutnya dilakukan pelindian asam menggunakan pelarut $\mathrm{HNO}_{3}$ dan selanjutnya dikeringkan serta dilanjutkan pelindian dengan $\mathrm{H}_{3} \mathrm{PO}_{4}$ dengan variasi konsentrasi dan selanjutnya dikeringkan. Rute proses penelitian pengkayaan unsur yttrium dan cerium pada terak timah Bangka-2 diperlihatkan pada Gambar 1.

\subsection{Karakterisasi dan Analisis}

Seluruh sampel terak timah Bangka-2 dikarakterisasi komposisi kimianya dengan menggunakan XRF (X-ray fluorescence), konsentrasi besi $(\mathrm{Fe})$ dan kalsium $(\mathrm{Ca})$ terlarut 
dalam filtrat dikarakterisasi dengan menggunakan AAS (atomic absorption spectroscopy). Software HSC Chemistry 6.0 digunakan untuk melihat analisis termodinamika yaitu untuk mendapatkan nilai $\Delta \mathrm{G}$ dan Diagram Pourbaix, sedangkan tautan www.chemiday.com digunakan untuk melakukan produk yang terjadi jika terdapat 2 reaktan dilakukan reaksi kimia.

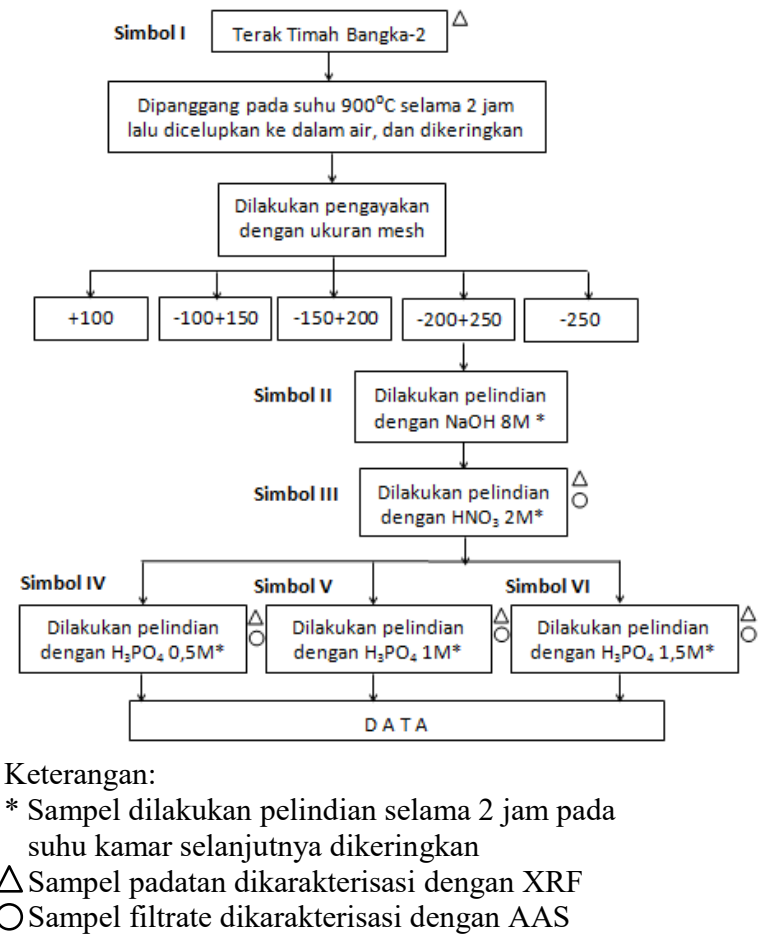

Gambar 1. Rute proses penelitian pengkayaan unsur yttrium dan cerium pada TTB-2

\section{Hasil dan Pembahasan}

Sampel terak timah Bangka-2 (TTB-2) dilakukan pemanggangan pada suhu $900{ }^{\circ} \mathrm{C}$ selama 2 jam yang dilanjutkan dengan pencelupan dalam air dengan maksud memperluas area pembasahan dengan tahapan merubah permukaan menjadi lebih poros karena kondisi patah dan retak akibat perlakukan panas, dengan merujuk pada penelitian sebelumnya [9]. Dengan memperluas area pembasahan, diharapkan kondisi proses pelindian akan lebih berhasil melarutkan oksida-oksida ikutan yang kurang berharga.

Pada proses pemanggangan dengan suhu $900{ }^{\circ} \mathrm{C}$ sudah tentu akan terjadi reaksi kimia jika kita melakukan tinjauan dengan Ellingham Diagram, namun pada penelitian ini kami belum melakukan pembahasannya, demikian juga halnya dengan hasil pemanggangan $900{ }^{\circ} \mathrm{C}$ yang dilakukan pencelupan ke dalam air, kami juga belum melakukan pembahasannya.

\subsection{Pemanggangan dan Pelindian dengan $\mathrm{NaOH}$}

Hasil pengayakan pada ukuran butir $-200+250$ mesh memperlihatkan seluruh kadar oksida yang tinggi, sekalipun kadar $\mathrm{Y}$ tertinggi pada ukuran butir $-100+150$ mesh yaitu $1,06 \%$ tetapi kadar Y pada ukuran butir $-200+250$ mesh $0,93 \%$ terjadi perbedaan yang sedikit sehingga ditetapkan sampel TTB-2 diambil ukuran butir 200+250 mesh.

Pelindian dengan $\mathrm{NaOH}$ mengacu pada penelitian sebelumnya [10], dimana dijelaskan bahwa pelindian TTB-2 dengan pelarut $\mathrm{NaOH}$ akan melarutkan oksida-oksida $\mathrm{Al}_{2} \mathrm{O}_{3}, \mathrm{Fe}_{2} \mathrm{O}_{3}$, dan $\mathrm{ZrO}_{2}$.

Tabel 2. Distribusi ukuran hasil pengayakan terak timah Bangka-2

\begin{tabular}{cccccccccc}
\hline $\begin{array}{c}\text { Distibusi } \\
\text { Ukuran(Mesh) }\end{array}$ & $\mathbf{Y}$ & $\mathbf{C e}$ & $\mathbf{S i O}_{2}$ & $\mathbf{T i O}_{2}$ & $\mathbf{F e}_{2} \mathbf{O}_{\mathbf{3}}$ & $\mathbf{S n}$ & $\mathbf{Z r}$ & $\mathbf{C a O}$ & $\begin{array}{c}\text { Total } \\
\text { (\%) }\end{array}$ \\
\hline+100 & 0,64 & 0,65 & 2,57 & 0,96 & 1,29 & 2,24 & 1,09 & & 9,44 \\
$-100+150$ & 1,06 & 1,33 & 6,3 & 2,43 & 2,58 & 3,21 & 1,92 & 0,86 & 19,69 \\
$-150+200$ & 0,88 & 1,27 & 4,68 & 1,82 & 2,01 & 2,63 & 1,52 & 0,03 & 14,84 \\
$-200+250$ & 0,93 & 3,93 & 12,89 & 3,32 & 4,17 & 7,06 & 4,05 & 4,42 & 40,77 \\
-250 & 0,89 & 1,01 & 4,75 & 1,78 & 1,97 & 2,93 & 1,55 & & 14,88 \\
\hline
\end{tabular}

Tabel 3. Data $\Delta \mathrm{G}$ reaksi oksida-oksida $\mathrm{SiO}_{2}, \mathrm{CaO}, \mathrm{TiO}_{2}$, $\mathrm{Fe}_{2} \mathrm{O}_{3}$ dan $\mathrm{ZrO}_{2}$ dengan $\mathrm{NaOH}$

\begin{tabular}{lc}
\hline \multicolumn{1}{c}{ Reaksi } & \multicolumn{1}{c}{$\boldsymbol{\Delta G}$ (kcal) } \\
\hline $\mathrm{SiO}_{2}+2 \mathrm{NaOH} \rightarrow \mathrm{Na}_{2} \mathrm{SiO}_{3}+\mathrm{H}_{2} \mathrm{O}$ & $-21,228$ \\
$\mathrm{CaO}+2 \mathrm{NaOH} \rightarrow \mathrm{Ca}(\mathrm{OH})_{2}+\mathrm{Na}_{2} \mathrm{O}$ & 21,047 \\
$6 \mathrm{TiO}_{2}+2 \mathrm{NaOH} \rightarrow \mathrm{Na}_{2} \mathrm{Ti}_{6} \mathrm{O}_{13}+\mathrm{H}_{2} \mathrm{O}$ & $-23,582$ \\
$\mathrm{Fe}_{2} \mathrm{O}_{3}+2 \mathrm{NaOH} \rightarrow 2 \mathrm{NaFeO}_{2}+\mathrm{H}_{2} \mathrm{O}$ & $-4,262$ \\
$\mathrm{ZrO}_{2}+2 \mathrm{NaOH} \rightarrow \mathrm{Na}_{2} \mathrm{ZrO}_{3}+\mathrm{H}_{2} \mathrm{O}$ & $-5,954$ \\
\hline
\end{tabular}

Dari Tabel 3 reaksi antara $\mathrm{NaOH}$ dengan $\mathrm{SiO}_{2}, \mathrm{TiO}_{2}, \mathrm{Fe}_{2} \mathrm{O}_{3}$, dan $\mathrm{ZrO}_{2}$ keseluruhannya memperlihatkan nilai $\Delta \mathrm{G}$ negatif, hal ini menunjukkan bahwa reaksi berlangsung secara spontan. Nilai $\Delta G$ reaksi yang bernilai positif terjadi hanya pada reaksi antara $\mathrm{CaO}$ dengan $\mathrm{NaOH}$. Hal ini menunjukkan bahwa reaksi berlangsung tidak spontan. Oleh karena itu kadar $\mathrm{CaO}$ setelah pelindian dengan $\mathrm{NaOH}$ tidak berkurang tetapi justru bertambah oleh karena senyawa oksida $\mathrm{SiO}_{2}, \mathrm{TiO}_{2}, \mathrm{Fe}_{2} \mathrm{O}_{3}$ dan $\mathrm{ZrO}_{2}$ terlarut sebagian. Karakterisasi komposisi kimia filtrat dengan AAS (atomic absorption spectroscopy) pada kondisi proses II diperlihatkan pada Tabel 4 dimana hasil filtrat memperlihatkan kadar kalsium yang tidak terdeteksi.

Tabel 4. Hasil karakterisasi AAS pada filtrat

\begin{tabular}{ccc}
\hline Kondisi Proses & Fe (ppm) & Ca (ppm) \\
\hline II & 31 & tidak terdeteksi \\
IV & 178,46 & $2.344,05$ \\
V & 190,70 & $2.447,90$ \\
VI & 267,69 & $2.659,00$ \\
\hline
\end{tabular}

Selain itu analisis mengapa kalsium diperkirakan tidak terlarut adalah dapat dilihat pada Diagram Pourbaix pada Gambar 2, dimana 
terlihat bahwa pada Diagram Pourbaix dengan sistem $\mathrm{Ca}-\mathrm{Na}-\mathrm{H}_{2} \mathrm{O}$, Ca pada pada $\mathrm{pH} 14,9$, akan stabil menjadi senyawa $\mathrm{Ca}(\mathrm{OH})_{2}, \mathrm{CaH}_{2}$ atau $\mathrm{CaO}$ yang padat, sehingga tidak akan terlarut pada saat pelindian dengan $\mathrm{NaOH} 8 \mathrm{M}$. Pada Gambar 7 terlihat juga peningkatan kadar $\mathrm{TiO}_{2}$ dan $\mathrm{Fe}_{2} \mathrm{O}_{3}$ pada kondisi proses II, sudah tentu hal ini berlawanan informasi dengan data pada Tabel 3 dimana nilai $\Delta \mathrm{G}$ nya negatif yang harusnya terlarutkan, hal ini akan menjadi tantangan pada penelitian berikutnya.

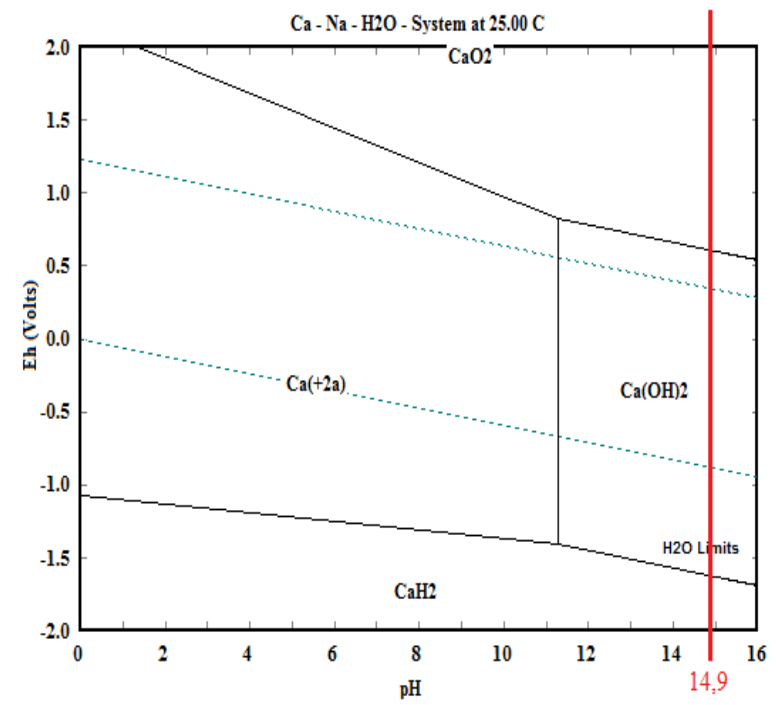

Gambar 2. Diagram Pourbaix sistem $\mathrm{Ca}-\mathrm{Na}-\mathrm{H}_{2} \mathrm{O}$ pada suhu $25^{\circ} \mathrm{C}$

Kenaikan kadar cerium dari kondisi proses I ke kondisi proses II terlihat sangat signifikan yaitu dari kadar $1,57 \%$ menjadi 4,39\%, hal ini dapat dijelaskan sebagai berikut: jika kita melihat Tabel 3 data $\Delta \mathrm{G}$ reaksi oksida-oksida $\mathrm{SiO}_{2}, \mathrm{CaO}$, $\mathrm{TiO}_{2}, \mathrm{Fe}_{2} \mathrm{O}_{3}$, dan $\mathrm{ZrO}_{2}$ dengan $\mathrm{NaOH}$ akan mendukung kenaikan kadar cerium. Namun ada hal utama yang menyebabkan kenaikan kadar cerium adalah pelarutan cerium ke dalam $\mathrm{NaOH}$ $8 \mathrm{M} \quad(\mathrm{pH}=13,097)$ menyebabkan cerium membentuk senyawa oksida cerium yaitu $\mathrm{CeO}_{2}$ atau senyawa $\mathrm{CeH}_{2}$, hal inilah yang membuat cerium tidak terlarutkan. Pembentukan senyawa $\mathrm{CeO}_{2}$ atau $\mathrm{CeH}_{2}$ dapat dijelaskan dengan Diagram Pourbaix sistem Ce-Na- $\mathrm{H}_{2} \mathrm{O}$ pada suhu $25^{\circ} \mathrm{C}$ yang ditunjukkan pada Gambar 4(a).

Penjelasan kenaikan kadar yttrium pada kondisi proses II dapat dilihat pada Gambar 4(b) dimana pelarutan yttrium dengan $\mathrm{NaOH} 8 \mathrm{M}$ $(\mathrm{pH}=13,097)$ menghasilkan senyawa $\mathrm{YH} 3$ dan $\mathrm{Y}(\mathrm{OH}) 3$ yang artinya yttrium tidak terlarutkan.

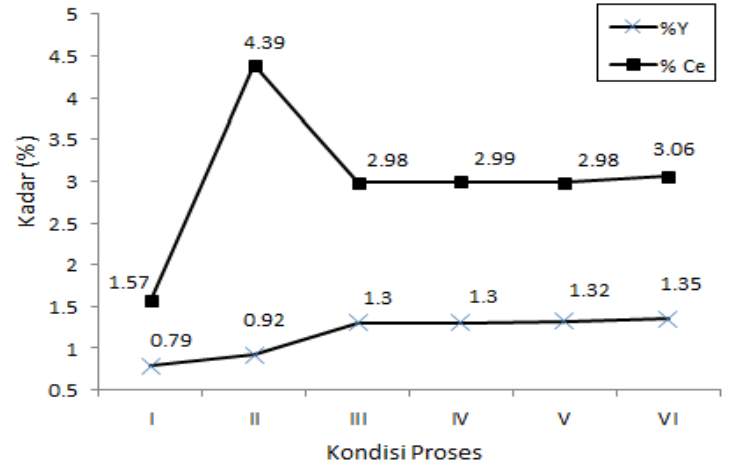

Gambar 3. Hasil karakterisasi XRF kadar yttrium dan cerium pada seluruh kondisi proses dalam TTB-2
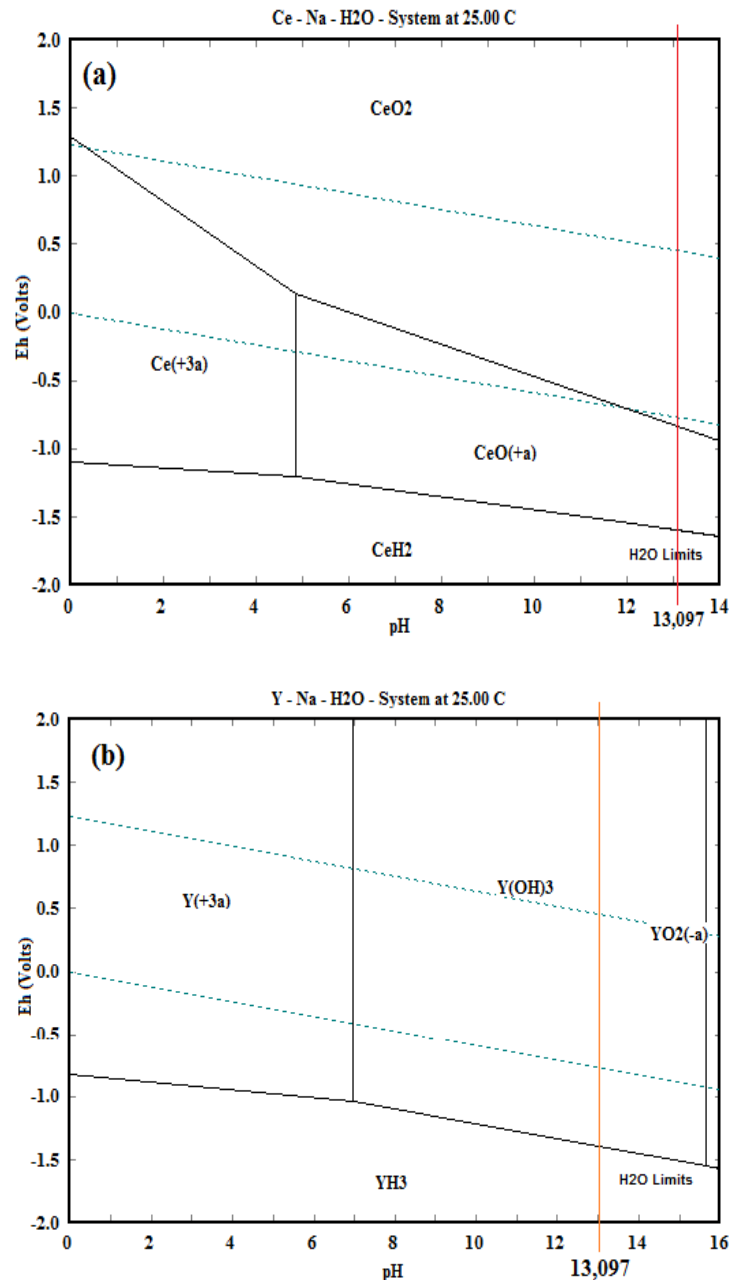

Gambar 4. Diagram Pourbaix sistem; (a) $\mathrm{Ce}-\mathrm{Na}-\mathrm{H}_{2} \mathrm{O}$, (b) $\mathrm{Y}-\mathrm{Na}-\mathrm{H}_{2} \mathrm{O}$ pada suhu $25^{\circ} \mathrm{C}$

\subsection{Pelarutan dalam Larutan $\mathrm{HNO}_{3}$}

Pada Gambar 3 terlihat kadar cerium dan yttrium pada residu hasil pelindian TTB-2 ke dalam larutan $\mathrm{HNO}_{3}$ (kondisi proses III). Kadar unsur cerium mengalami penurunan drastis dari $4,39 \%$ menjadi $2,98 \%$. Sedangkan unsur yttrium mengalami kenaikan dari $0,92 \%$ menjadi $1,3 \%$.

Penjelasan penurunan kadar cerium dan kenaikan kadar yttrium akan dijelaskan pada Gambar 5 dengan menggunakan analisis termodinamika menggunakan Diagram Pourbaix. 
Gambar 5(a) memperlihatkan Diagram Pourbaix sistem Ce- $-\mathrm{N}_{2} \mathrm{O}$, pada $\mathrm{pH}=-0,301$ cerium terlarut dalam bentuk $\mathrm{Ce}^{+3}$ dan $\mathrm{CeNO}_{3}{ }^{+2}$. Jadi cerium mengalami penurunan karena terlarutkan sehingga kadar cerium di dalam TTB2 mengalami penurunan.
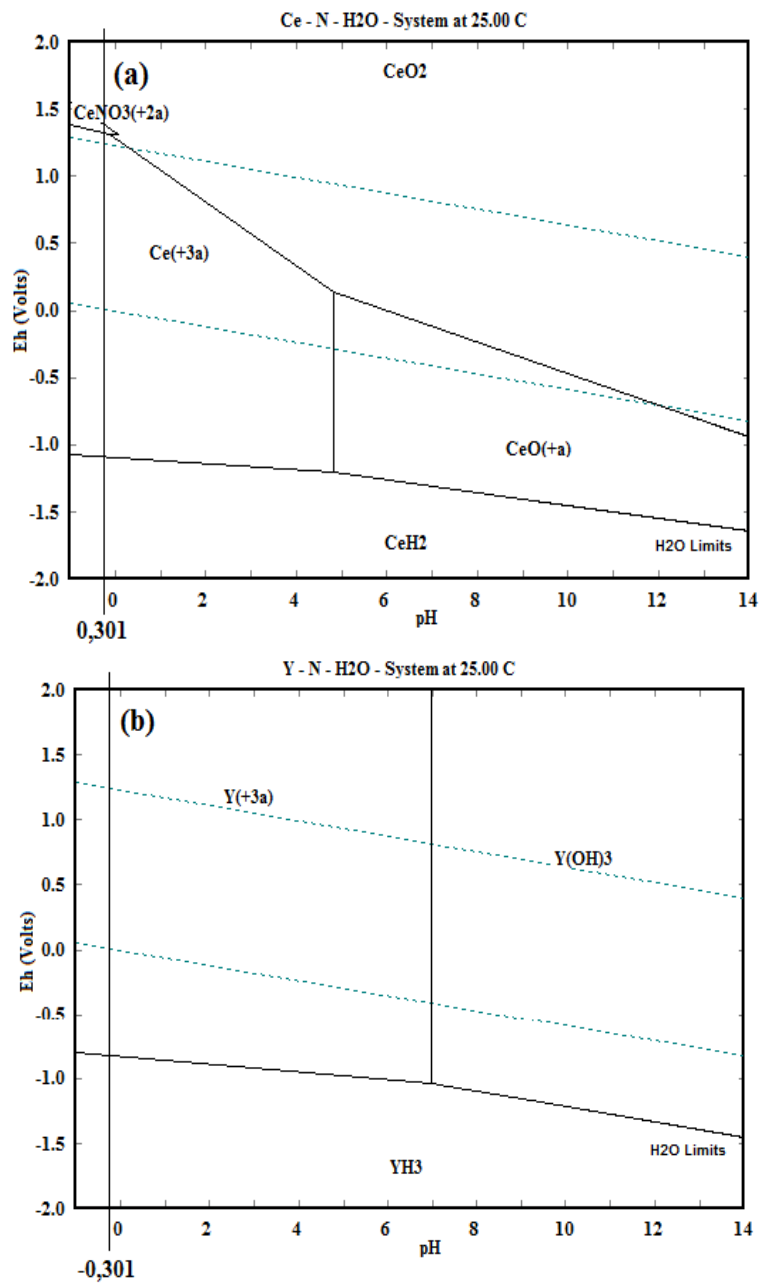

Gambar 5. Diagram Pourbaix sistem; (a) $\mathrm{Ce}-\mathrm{N}-\mathrm{H}_{2} \mathrm{O}$, (b) $\mathrm{Y}-\mathrm{N}-\mathrm{H}_{2} \mathrm{O}$ pada suhu $25^{\circ} \mathrm{C}$

Jika kita perhatikan pada Gambar 3, pada kondisi proses III kadar yttrium mengalami kenaikan, Diagram Pourbaix pada Gambar 5(b) dapat membantu untuk menjelaskan kenaikan kadar yttrium tersebut. Pada gambar tersebut yttrium berbentuk $\mathrm{YH}_{3}$ dan $\mathrm{Y}^{3+}$ artinya kemungkinan saja yttium terlarutkan dalam bentuk ion $\mathrm{Y}^{3+}$ atau tidak terlarutkan dalam bentuk senyawa $\mathrm{YH}_{3}$.

Jika yttrium terlarutkan maka keterlarutannya harus dibandingkan dengan keterlarutan oksida $\mathrm{CaO}$. Jika ternyata kadar yttrium meningkat, kemungkinan terbesar adalah keterlarutan yttrium jauh lebih kecil dari keterlarutan oksida $\mathrm{CaO}$. Indikasi keterlarutan oksida $\mathrm{CaO}$ yang besar dapat dilihat pada Gambar 7 dan 8. Jika kita bandingkan antara Gambar 3, 7 dan 8 kita bisa melihat kenaikan kadar cerium dari kondisi proses II ke kondisi proses III adalah 41,3\%
$([1,3-0,92] /[0,92] \times 100 \%)$ sedangkan penurunan kadar $\mathrm{CaO}$ adalah 43,26 \% ([4,53-2,57]/ $[4,53] \times 100 \%)$.

\subsection{Pelarutan dalam Larutan $\mathrm{H}_{3} \mathrm{PO}_{4}$}

Pada Gambar 3 kadar cerium dan yttrium hasil pelindian TTB-2 ke dalam larutan $\mathrm{H}_{3} \mathrm{PO}_{4}$ (kondisi proses IV, V dan VI). Kadar unsur cerium mengalami kenaikan bertahap dari 2,99\% dan terakhir $3,06 \%$. Sedangkan unsur yttrium mengalami kenaikan dari $1,3 \%$ dan terakhir $1,35 \%$.

Penjelasan kenaikan kadar cerium dan yttrium akan dijelaskan di bawah dengan menggunakan analisis termodinamika menggunakan Diagram Pourbaix.
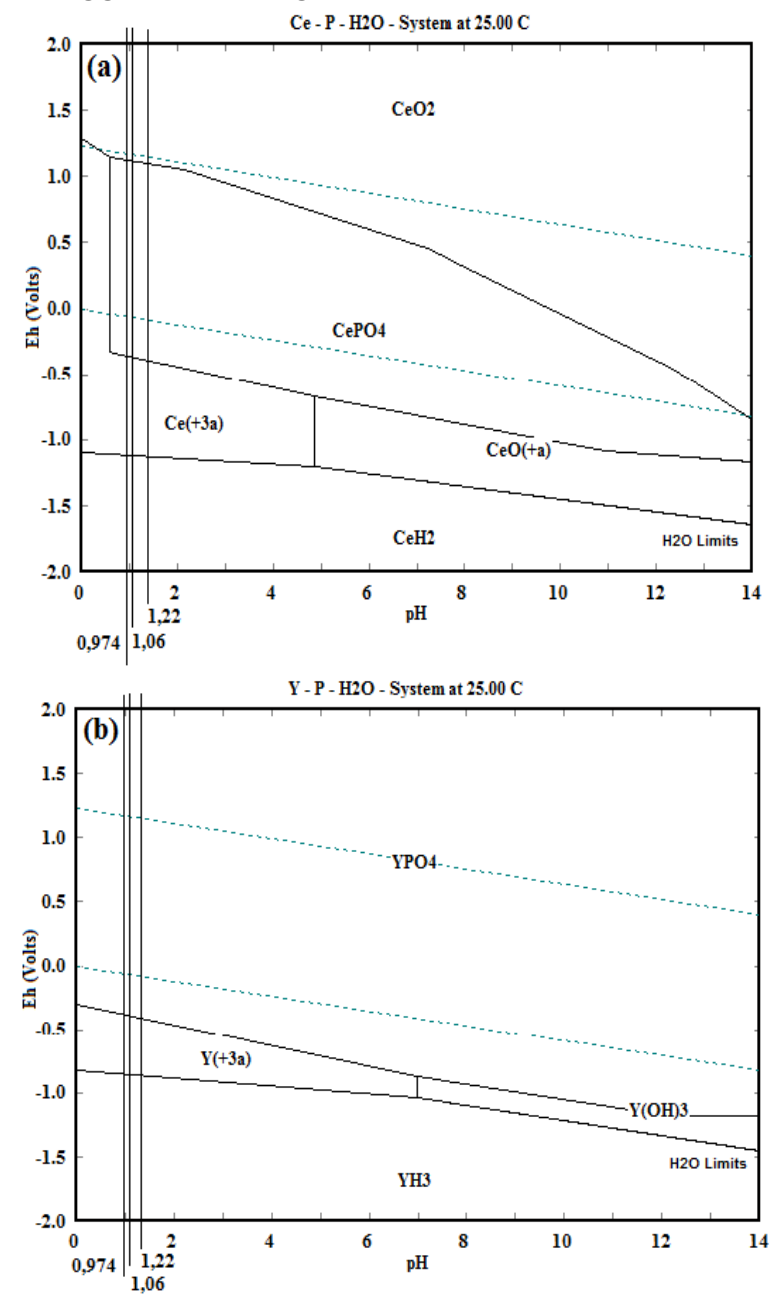

Gambar 6. Diagram Pourbaix sistem (a) Ce-P- $\mathrm{H}_{2} \mathrm{O}$, (b) Y-P-H $\mathrm{H}_{2} \mathrm{O}$ pada suhu $25^{\circ} \mathrm{C}$

Karena $\mathrm{H}_{3} \mathrm{PO}_{4}$ merupakan asam lemah maka menentukan konsentrasi $\mathrm{H}^{+}$-nya harus menggunakan $\mathrm{K}_{\mathrm{a}}$ dengan nilai 7,5 x $10^{-3}$. Dengan data tersebut didapat $\mathrm{pH} \mathrm{H}_{3} \mathrm{PO}_{4}$ pada $0,5 \mathrm{M}, 1 \mathrm{M}$ dan $1,5 \mathrm{M}$ adalah 1,$22 ; 1,06$ dan 0,974 .

Untuk unsur cerium, dari ketiga $\mathrm{pH}$ tersebut dan kita korelasikan dengan diagram Pourbaix seperti pada Gambar 6(a), disana terlihat pelindian cerium dengan $\mathrm{H}_{3} \mathrm{PO}_{4}$ pada ketiga $\mathrm{pH}$ 
lebih dominan menghasilkan senyawa $\mathrm{CeO}_{2}$, $\mathrm{CePO}_{4}$ dan $\mathrm{CeH}_{2}$. Sehingga dari senyawa tersebut memperlihatkan bahwa unsur cerium kurang terlarutkan pada kondisi proses IV, V dan VI.

Hal lain yang mendukung kenaikan kadar cerium adalah terlarutkannya $\mathrm{SiO}_{2}$ pada kondisi proses IV, V dan VI, informasi tentang hal ini dapat dilihat pada Gambar 7.

Boussaa, dkk., [11] melakukan pelindian pasir silika dengan $\mathrm{HNO}_{3}$ selama 2,5 jam, dan hasilnya memperlihatkan penurunan kandungan $\mathrm{Al}$ dan $\mathrm{Fe}$ yang sangat signifikan. Besar persentasi Fe yang dihilangkan mencapai 90,5\% dan untuk Al sebesar 87,3\%. Kemudian untuk agen pelindi $\mathrm{H}_{3} \mathrm{PO}_{4}$ lebih banyak melarutkan $\mathrm{Fe}$ dan Al dibanding $\mathrm{HNO}_{3}$, yaitu secara berturutturut sebesar 97,62 \% dan 91,15\%. Terak peleburan timah mengandung $\mathrm{Si}, \mathrm{Fe}$, dan $\mathrm{Al}$ yang berikatan dengan $\mathrm{Ca}$, maka pada saat pelindian dalam larutan asam nitrat akan mengalami pelarutan $\mathrm{Ca}, \mathrm{Al}$, dan $\mathrm{Fe}$, yang mengakibatkan keruntuhan struktur ikatan, dan melepaskan partikel-partikel halus $\mathrm{SiO}_{2}$ sebagai larutan koloid [12].

Hal ini juga serupa dengan penjelasan yang termuat pada artikel yang ditulis oleh C.Subramanian dan A.K Suri [13], bahwa pelindian asam akan melarutkan $\mathrm{Al}, \mathrm{Fe}$, dan $\mathrm{Ca}$, dengan persen terlarut paling tinggi pada senyawa $\mathrm{Al}$, diikuti $\mathrm{Ca}$ dan $\mathrm{Fe}$.

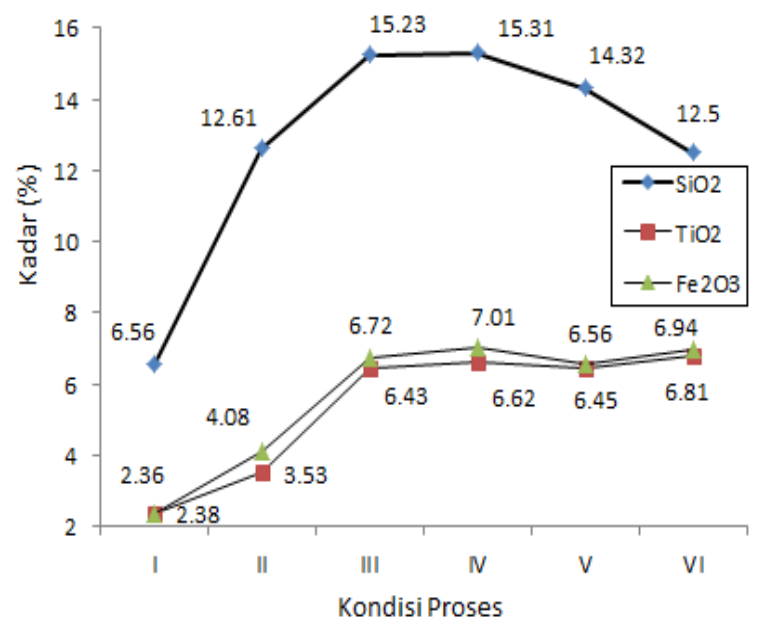

Gambar 7. Hasil karakterisasi XRF kadar $\mathrm{SiO}_{2}, \mathrm{TiO}_{2}$ dan $\mathrm{Fe}_{2} \mathrm{O}_{3}$ pada seluruh kondisi proses TTB-2

Seperti pada unsur cerium, kenaikan unsur yttrium salah satunya didukung oleh terlarutkannya $\mathrm{SiO}_{2}$ pada kondisi proses IV, V dan VI, sebagaimana dapat dilihat pada Gambar 7.

Pelindian yttrium dengan $\mathrm{H}_{3} \mathrm{PO}_{4}$ pada ketiga variasi $\mathrm{pH}$ lebih dominan menghasilkan senyawa $\mathrm{YPO}_{4}$ dan $\mathrm{YH}_{3}$. Dengan adanya senyawa $\mathrm{YPO}_{4}$ dan $\mathrm{YH}_{3}$ tersebut memperlihatkan bahwa unsur yttrium kurang terlarutkan pada kondisi proses IV, V dan VI.

Penelitian lain yang menggunakan pelindian dengan $\mathrm{H}_{3} \mathrm{PO}_{4}$ dan $\mathrm{HNO}_{3}$ dilaporkan oleh Zhang, dkk., [14], dimana pelarutan besi yang terus meningkat seiring naiknya konsentrasi $\mathrm{H}_{3} \mathrm{PO}_{4}$ yang dicampur ke dalam $\mathrm{HNO}_{3} 2 \mathrm{M}$. Hal ini dijelaskan bahwa dengan adanya ion $\mathrm{H}^{+}$yang disediakan oleh asam kuat $\mathrm{HNO}_{3}$, akan bereaksi dengan senyawa besi yang mengakibatkan besi akan terlarut ke dalam filtrat pelindian. Reaksinya adalah sebagai berikut:

$6 \mathrm{H}^{+}+\mathrm{Fe}_{2} \mathrm{O}_{3} \rightarrow 2 \mathrm{Fe}^{3+}+3 \mathrm{H}_{2} \mathrm{O}$

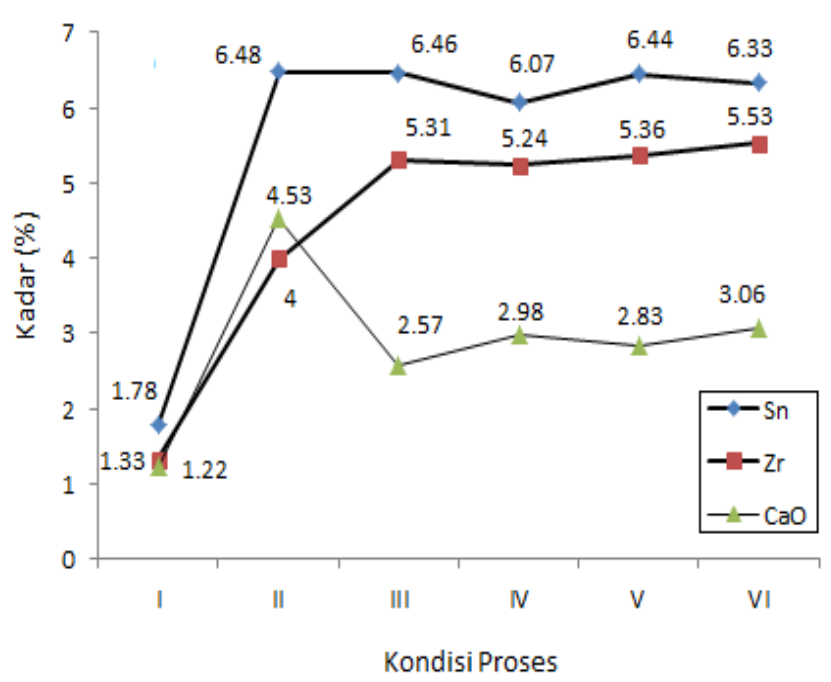

Gambar 8. Hasil karakterisasi XRF kadar Sn, $\mathrm{Zr}$ dan $\mathrm{CaO}$ pada seluruh kondisi proses TTB-2

Ditambah juga dengan adanya disosiasi $\mathrm{H}_{3} \mathrm{PO}_{4}$ yang menyediakan ion $\mathrm{H}^{+}(\mathrm{pKa}=2,12)$, yang akan bereaksi juga dengan senyawa oksida, selain itu ion $\mathrm{PO}^{3-}$ yang hadir karena dissosiasi $\mathrm{H}_{3} \mathrm{PO}_{4}$, dan memiliki kemampuan membentuk ion kompleks dengan besi, dan membuat besi akan terus terlarut ke dalam filtrat. Reaksinya adalah sebagai berikut [14]:

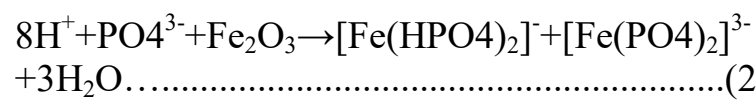

Ion-ion hidrogen ini akan terabsorpsi ke permukaan oleh karena adanya aktivasi permukaan. Ion hidrogen akan teradsorpsi ke permukaan padatan, dan membuat adanya pusat permukaan yang aktif, dimana pada kondisi tersebut akan menjadi letak pelarutan senyawa besi. Semakin banyaknya permukaan yang aktif, maka laju pelindian akan semakin besar [14]. 


\section{KeSIMPULAN}

Dari hasil penelitian di atas didapatkan informasi kadar optimum dari unsur cerium dan yttrium setelah TTB-2 dilakukan pemanggangan $900{ }^{\circ} \mathrm{C}$, pelindian dengan $\mathrm{NaOH}$, pelindian dengan $\mathrm{HNO}_{3}$, dan pelindian dengan $\mathrm{H}_{3} \mathrm{PO}_{4}$ dengan variasi konsentrasi.

Pengkayaan kadar cerium optimum didapatkan setelah terak timah yang telah mengalami pemanggangan pada suhu $900^{\circ} \mathrm{C}$ dan ukuran butirnya $+200-250$ mesh dilakukan pelindian dengan $\mathrm{NaOH} 8 \mathrm{M}$. Kadar cerium yang didapatkan pada kondisi proses tersebut 4,59\%.

Kadar yttrium meningkat pada seluruh kondisi proses, dan nilai kadar optimum didapat setelah kondisi proses pelindian dengan $\mathrm{HNO}_{3}$ $2 \mathrm{M}$ yang dilanjutkan dengan kondisi proses pelindian dengan $\mathrm{H}_{3} \mathrm{PO}_{4} 1,5 \mathrm{M}$. Kadar yttrium yang didapatkan pada kondisi proses tersebut $1,35 \%$.

\section{UCAPAN TERIMA KASIH}

Terimakasih kepada Centre of Mineral Processing and Corrosion Research Departemen Teknik Metalurgi and Material Universitas Indonesia yang telah memfasilitasi penelitian ini dan PT Timah Tbk. yang telah memberi sampel terak timah.

\section{Daftar Pustaka}

[1] V. Balaram, "Rare earth elements: A review of applications, occurrence, exploration, analysis, recycling, and environmental impact," Geosci. Front., vol. 10, no. 4, pp. 1285-1303, 2019.

[2] N. Clavier, R. Podor, dan N. Dacheux, "Crystal chemistry of the monazite structure," J. Eur. Ceram. Soc., vol. 31, no. 6, pp. 941-976, 2011.

[3] G. Konopka, K. Zglinicki, dan B. M. Maliszewska, "New potential source of rare earth elements," Gospod. SUROWCAMI Miner., vol. 29, no. 4, pp. 59-76, 2013.

[4] S. Permana, A. Rustandi, dan R. A. Majid, "Thermodynamic analysis with software: A case study of upgrading rare earth elements content in Bangka tin slag," Far East J. Electron. Commun., vol. 17, no. 5, pp. 1211-1220, 2017.

[5] A. B. Botelho Junior, D. C. R. Espinosa, dan J. A. S. Tenório, "The use of computational thermodynamic for yttrium recovery from rare earth elements-bearing residue," J. Rare Earths, 2020. Doi.org/10.1016/j.jre.2020.02.019.

[6] J. Liu, L. Zeng, S. Liao, X. Liao, J. Liu, J.
Mao, Y. Chen, T. Qiu dan S. Ren, "Highly efficient enrichment and adsorption of rare earth ions (yttrium(III)) by recyclable magnetic nitrogen functionalized mesoporous expanded perlite," Chinese Chem. Lett., 2020. Doi.org/10.1016/j.cclet.2020.08.017.

[7] S. Gerasin, D. Kalisz, dan J. Iwanciw, "Thermodynamic and kinetic simulation of Y2O3 and Y2S3 nonmetallic phase formation in liquid steel," J. Min. Metall. Sect. B Metall., vol. 56, no. 1, pp. 11-25, 2020.

[8] O. Eremin, O. Rusal, M. Solodukhina, E. Epova, dan G. Yurgenson, "Thermodynamic equilibria of tailings dump pond water of Sherlovaya Gora tin-polymetallic deposit (Transbaikalia)," in E3S Web of Conferences, vol. 98, no. 1014, pp. 1-6, 2019.

[9] S. Permana, S. F. Vincia, A. Amilia, A. Maksum, K. S. Widana, dan J. W. Soedarsono, "Enrichment on Bangka tin slag's tantalum and niobium oxide contents through non-fluoride process," EasternEuropean J. Enterp. Technol., vol. 5, no. 12-95, pp. 56-64, 2018.

[10] A. M. K. S. W. K. Trinopiawan, J W. Soedarsono, S. Permana, J. K. Hutauruk, R. Adhyputra, dan A Rustandi, "Upgrading tantalum and niobium oxides content in Bangka tin slag with double leaching Upgrading tantalum and niobium oxides content in Bangka tin slag with double leaching," in IOP Conf. Series: Materials Science and Engineering, pp. 1-9, 2018.

[11] S. A. Boussaa, A. Kheloufi, N. Boutarek Zaourar, dan S. Bouachma, "Iron and aluminium removal from Algerian silica sand by acid leaching," Acta Phys. Pol. A, vol. 132, no. 3, pp. 1082-1086, 2017.

[12] I. Gaballah, E. Allain, M.C. M. Joly, dan K. Malau, "A possible method for the characterization of amorphous slags recovery of refractory metal oxides from tin slags," Metall. Trans., vol. 23, pp. 249-259, 1992.

[13] C. Subramanian dan A. K. Suri, "Recovery of niobium and tantalum from low grade tin slag - A hydrometallurgical approach," Environ. Waste Manag., vol. 831, no. 7, pp. 100-107, 1998.

[14] F. K. Crundwell, "The dissolution and leaching of minerals: Mechanisms, myths and misunderstandings," Hydrometallurgy, vol. 139, pp. 132-148, 2013. 
52 | Metalurgi, V. 35.2.2020, P-ISSN 0126-3188, E-ISSN 2443-3926/ 45-52 